DISTRIBUTION STATEMENT A. Approved for public release; distribution is unlimited.

\title{
Transition funding for the Shallow Water Integrated Mapping System (SWIMS) and Modular Microstructure Profiler (MMP)
}

\author{
Matthew H. Alford \\ Scripps Institution of Oceanography \\ 9500 Gilman Drive, mail code 0213 \\ La Jolla, CA 92093 \\ phone: (858) 246-1646_email: malford@ucsd.edu \\ Grant Number: N00014-12-1-0917 \\ http://wavechasers.ucsd.edu/
}

\section{LONG-TERM GOALS}

I am interested in the general problems of internal waves and ocean mixing. Knowledge of these is important for advancing the performance of operational and climate models, as well as for understanding local problems such as pollutant dispersal and biological productivity. SWIMS and MMP are valuable, highly capable instruments that will enable me to participate in many future ONR initiatives, complementing my other suite of moored profiling instruments.

\section{OBJECTIVES}

- Transition the Shallow Water Integrated Mapping System (SWIMS) and Modular Microstructure Profiler (MMP) instrumentation from Mike Gregg’s group to mine.

\section{APPROACH}

Shallow Water Integrated Mapping System (SWIMS) Towed behind a ship, SWIMS is winched up and down from the surface to about 500-600 m depending on tow speed, which can range from 0-6 knots. It carries up and downlooking ADCP's, two pumped CTD's, optical backscatter, and a newly de- veloped temperature microstructure package ( $\chi$-ometer). The velocity measurements obtained from SWIMS are substantially better than those obtained from a shipboard ADCP because they can get much closer to the bottom. Additionally, SWIMS allows tighter sawtooths than similar undulating bodies such as Triaxus and Seasoar, and can be operated much closer to steep topography.

Modular Microstructure Profiler (MMP) is a loosely tethered microstructure profiler that carries a pumped CTD, and shear probes and FP07 thermistors for velocity and temperature microstructure. With a noise floor near $10-10 \mathrm{~W} \mathrm{~kg}-1$, it is one of the most sensitive microstructure instruments available. It is deployed from the stern of the ship with a twisted-pair cable, requiring a team of three people per shift to operate. MMP can be operated in time series or along transects, providing repeated profiles of dissipation, diffusivity and buoyancy flux. Profiles to $300 \mathrm{~m}$ can be done every 15-20 minutes. Dissipation rates are calculated from shear probe data using standard techniques. Importantly, 


\section{Report Documentation Page}

Form Approved

OMB No. 0704-0188

Public reporting burden for the collection of information is estimated to average 1 hour per response, including the time for reviewing instructions, searching existing data sources, gathering and maintaining the data needed, and completing and reviewing the collection of information. Send comments regarding this burden estimate or any other aspect of this collection of information,

including suggestions for reducing this burden, to Washington Headquarters Services, Directorate for Information Operations and Reports, 1215 Jefferson Davis Highway, Suite 1204, Arlington

VA 22202-4302. Respondents should be aware that notwithstanding any other provision of law, no person shall be subject to a penalty for failing to comply with a collection of information if it

does not display a currently valid OMB control number.

1. REPORT DATE

30 SEP 2014

4. TITLE AND SUBTITLE

Transition funding for the Shallow Water Integrated Mapping System (SWIMS) and Modular Microstructure Profiler (MMP)

6. AUTHOR(S)

7. PERFORMING ORGANIZATION NAME(S) AND ADDRESS(ES)

University of California San Diego,Scripps Institution of Oceanography,9500 Gilman Drive,La Jolla,CA,92093

9. SPONSORING/MONITORING AGENCY NAME(S) AND ADDRESS(ES)

3. DATES COVERED

00-00-2014 to 00-00-2014

5a. CONTRACT NUMBER

5b. GRANT NUMBER

5c. PROGRAM ELEMENT NUMBER

5d. PROJECT NUMBER

5e. TASK NUMBER

5f. WORK UNIT NUMBER

8. PERFORMING ORGANIZATION REPORT NUMBER

10. SPONSOR/MONITOR'S ACRONYM(S)

11. SPONSOR/MONITOR'S REPORT NUMBER(S)

12. DISTRIBUTION/AVAILABILITY STATEMENT

Approved for public release; distribution unlimited

13. SUPPLEMENTARY NOTES

14. ABSTRACT

15. SUBJECT TERMS

16. SECURITY CLASSIFICATION OF:

a. REPORT

unclassified b. ABSTRACT

unclassified c. THIS PAGE

unclassified
17. LIMITATION OF ABSTRACT

Same as

Report (SAR)
18. NUMBER 19a. NAME OF

OF PAGES RESPONSIBLE PERSON

3 
MMP uses pumped conductivity probes, unlike most other microstructure profilers, giving much better precision in salinity estimates.

\section{WORK COMPLETED}

Thanks to a related grant to study Washington coast internal waves, we have transitioned MMP and SWIMS to Scripps. We first needed to repair one of the MMP's, which had a slight leak. We successfully operated both of these instruments during our August 2014 cruise.

\section{RESULTS}

We observed beautiful breaking lee waves in repeated alongchannel transects over a sill in the canyon (Figure 1). We wrote these measurements up in a GRL note.

\section{TRANSITIONS}

These instruments were developed at APL/UW by Mike Gregg. Following his wishes, they are now at Scripps with me, and will be operated by my group here.

\section{RELATED PROJECTS}

SWIMS and MMP were used in our Washington coastal nonlinear internal waves project.

\section{PUBLICATIONS}

Matthew H Alford and Parker MacCready. Flow and mixing in Juan de Fuca Canyon, Washington. Geophys. Res. Lett., 41:1-8, 2014. 


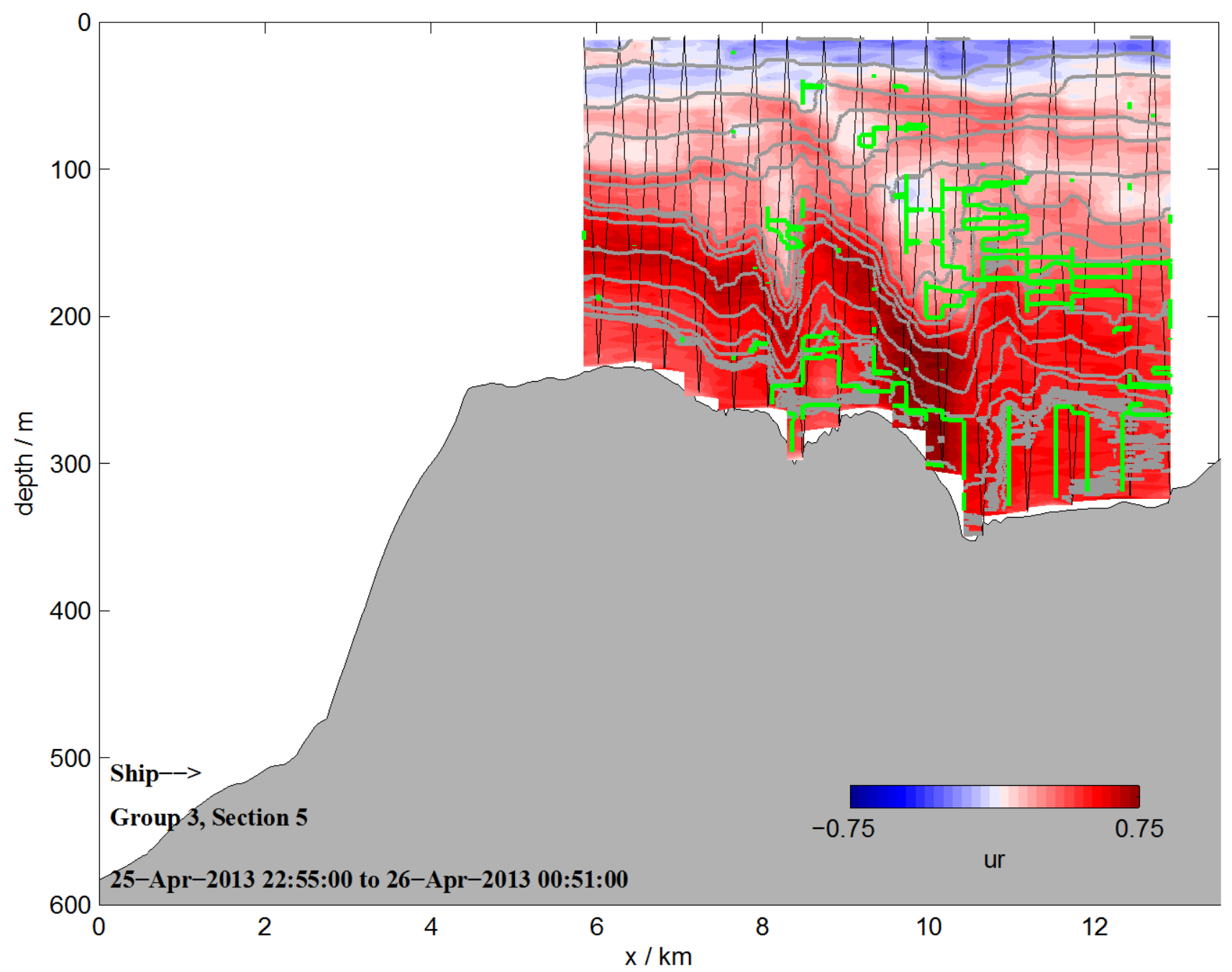

Figure 1: Alongcanyon velocity from a one-hour tow from left to right with SWIMS over a sill in Juan de Fuca submarine Canyon, Washington. Flow is strongly accelerated transiting the sill at $\mathrm{km} 6$, reaching over $75 \mathrm{~cm} / \mathrm{s}$ as it descends. Internal lee waves are seen near $\mathrm{km} 8$ and 11, whose breaking gives rise to strong turbulence (estimated from Thorpe scales; green contours indicate $\varepsilon>$ $\left.10^{-6} \mathrm{~W} / \mathrm{kg}\right)$. The sawtooth lines indicate SWIMS's track. 